\title{
Does Forest Certification Improve Socio-Economic and Governance Issues? A Case of Community Forestry from Nepal
}

\author{
Acharya $\mathbf{R P}^{1,2 *}$ and Gyanendra Karki ${ }^{3}$ \\ ${ }^{1}$ Director, Nepal \\ ${ }^{2} \mathrm{PhD}$ Scholar, Australia \\ ${ }^{3}$ Program Director, Nepal
}

\begin{abstract}
Forest certification has emerged as a market-based solution to improve forest management, and also expected that it can contribute in resource governance and poverty reduction. Nepal's community forestry is an exemplary participatory forest management system and a total of 18,960 community forest user groups (CFUGs) are managing 1.79 million hectares of national forest land. Selecting two CFUG, one each from Central and Far-Western Nepal, and using longitudinal method, the study analysed the impacts that the forest certification has brought in constitutions, operational plans, minutes and their record keeping systems. Moreover, the implementation status of those changes in regard to decision making, governance, institutional development and livelihood enhancement has been studied. Three time series $(2003,2008$ and 2016) data were used to assess change in socio-economy and governance through forest certification. The results indicated that the certification has played an important role for local value addition of non-timber forest products, income and employment generation, and rural poverty reduction. It has also positive impacts in sustainable resource management through improved governance. The signs of major positive changes in resource management were but not limited to improved collection practices, up-to-date record keeping, and maintaining transparency of all process and methods. This has also resulted improvement in forest management and local enterprises promotion. The study suggests that the forest certification in community managed forests can be beneficial to improve natural resource governance, ultimately contributing in reducing poverty.
\end{abstract}

KEYWORDS: Forest certification; Community based forest management; Multiple impacts; Poverty reduction; Sustainable forest management

ABBREVIATIONS: FC: Forest Certification; CFUGs: Community Forest User Groups; NR: Natural Resources; CBFC: Community-based Forest Certification; FSC: Forest Stewardship Council; CFs: Community Forests; OP: Operational Plan; DFO: District Forest Office; AAC: Annual Allowable Cut; MAPs: Medicinal and Aromatic Plants; HBTL: Himalayan Biotrade

Quick Response Code: $\quad$ Address for correspondence: Acharya RP, Director at Practical Solution Consultancy, PhD Scholar at University of Southern Queensland, Australia

Received: August 25, 2019 Published: October 08, 2019

How to cite this article: Acharya RP, Does Forest Certification Improve Socio-Economic and Governance Issues? A Case of Community Forestry from Nepal. 2019 - 1(2) OAJBS. ID.000106. DOI: $10.38125 / \mathrm{OAJBS} .000106$ 


\section{BACKGROUND}

Over the last two decades, forest certification (FC) has been emerged as a market-oriented policy instrument in forestry sector. Nepal's community forestry is an exemplary participatory forest management system. There are 18,960 community forest user groups (CFUGs) managing 1.79 million hectares of national forest land, involving above 1.7 million households, and 23,92,755 population [1]. FC is voluntary in nature and mostly involves nonstate actors in environment policy control. It is one of the most leading market dynamics in forestry and other forest products sectors, with its overarching goal of promoting sustainable forest management. It is believed that, one of the aims of $\mathrm{FC}$ is to provide reliable, credible information for end users of forest products [2,3]. Credible certification is thus anindependent system of evaluating forestry with an aim of promoting internationally recognized best practices for forest management. FC urged direct benefits for forest organizations (and the managers or owners involved) against the costs. In essence, it has mainly two functions; first is to improve the environmental, social and economic quality of forest management and second, it requires maintenance of records and improved market access or share of forest products and functions and gain economic benefits $[4,5]$. In most cases, $\mathrm{FC}$ has been promoted to enhance forest management in countries where governance capacities are insufficient to adequately manage natural resources (NR) and enforce pertinent regulations, given that certification relies largely on non-governmental organizations and private business [2].

Community-based Forest Certification (CBFC) has raised a significant interest with an aptitude to contribute in poverty alleviation $[3,6]$. Most people working in forestry caneasily list a number of areas where FC has had an impact on the management of a particular forest, a group of forest-dependent people or particular resource governance. FC was introduced in community forests of Nepal under Forest Stewardship Council (FSC) certification scheme by ANASB in 2004 whereby 14,086 ha of Community Forests (CFs) were certified in two districts namely Bajhang and Dolakha. Now it has been expanded to above 17,146 hectares incorporating payment for ecosystem services [7]. However, there's is no information on how the introduction of FC in those pilot CFUGs has changed forest governance and livelihood improvement. Therefore, this paper analyzed the multidimensional socio-economic and governance impacts of FC in those CFs and its implications for enhancing sustainable forestry and resource governance in context of community forestry of Nepal.

\section{METHODOLOGY}

Longitudinal method, an observational research method, in which data are gathered for the same subject or issue repeatedly over a period of time [8], was applied to study FC impacts on social-economic and governance. The method analysedchanges of constitutions, operational plans, minutes and their record keeping systems, etc. in studied CFUGs. Theimplementation status of constitution and operation plan,documentation and decisionmaking process, forest governance, institutional development, and livelihood and economic development through forest products and contribution to resource conservation between 2003, 2008 and 2016 were studied. Out of 35 certified CFUGs of Bajhang and Dolakha districts [9], the study focused mainly two representative CFUGs: Kalobhir CFUG of Jiri VDC-7, Dolakha and Lahare CFUG of Gadaraya VDC-9, Bajhang. Forest area of Kalobhir CFUG was 545 ha [10-13] Lahare CFUG, (2008); Lahare CFUG (2016). The samples were purposefully selected for comparative assessment in terms of socio-economic impacts and transformations from East to West followingfree-listing, and stakeholders and key informants consultations.

Both primary and secondary sources of information, as well as qualitative and quantitative data on biophysical, socio-cultural and economic aspects of sustainable forest management, FC, and NTFP marketing were gathered from literatures. Key informant survey, informal interviews and telephone interviews were also conducted. Operational plans and constitutions of sample CFUGs, annual and final reports of certification project, academic research reports and journal articles $[2,3,14]$ on FC and its impact were reviewed. Above 60 respondents from all levels ranging from collectors to officers of district line agencies were consulted during the study. In particular, representatives from District Forest Office, FECOFUN and users and executive committee members of sample CFUGs were consulted. Inter and intra CFUGs level assessment on socio-economic and governance issues was made to compare the results.

Findings of the study were dividedinto two major themes; socio-economic and governance impacts. Impacts on governance covered the improvement in operational plan development, mainly the content and process such as conducting inventory of major commercial species and formulation of management provisions for them; improvement on community-based biodiversity monitoring mechanism and implementation especially on mapping of high conservation value forest areas etc. Identification and priority settings to poor households, voice raised by poor householdsand the ways they are responded, , increased awareness level on value addition, and safety measures in forest product collection and processingwere taken into consideration in social impact assessment. Economic impact assessment included increase in local demand and price of forest products, additional income and employment from forest management and establishment of local value-addition facilities, employment through local value addition and international market linkages of certified products with a good price.

\section{FINDINGS AND DISCUSSION}

\section{Membership and participation}

The constitutions of the selected CFUGs were revised in 2004 and 2015 to adopt sustainable forest management and certification requirement. The major change was found in structure and function of the executive committee. The participation of women, ethnic and poor households was increased significantly and even continued in 2016 too (Table 1 ).

\section{Content of CFUG operational plan}

To be eligible for certification process, a forest management plan with better social and environmental considerations is a prerequisite [15]. Operational plan (OP) is the basic document for forest management in CBFM of Nepal [16]. Basically, CF management runs under CFUG operational plan and forest act, though other several rules and regulation are taken into consideration while preparing the OP. The management plan guides and regulates forest management and requires renewing in every five to ten years depending upon the terms and condition agreed with District Forest Office (DFO). In both CFUGs, operational plan and constitution were developed based on consensus and consecutively improved from 2003 situation. The general outlines of operational plan were as follows: 
Table 1: Total number, women, Dalit and poor HHs participation in executive committee in 2003, 2008 and 2016.

\begin{tabular}{|c|c|c|c|c|c|c|c|c|}
\hline \multirow{2}{*}{ Major Areas } & \multicolumn{3}{|c|}{ Kalobhir CFUG } & \multirow[t]{2}{*}{ Change (\%) } & \multicolumn{3}{|c|}{ Lahare CFUG } & \multirow[t]{2}{*}{ Change (\%) } \\
\hline & 2003 & 2008 & 2016 & & 2003 & 2008 & 2016 & \\
\hline No of executive members & 13 & 13 & 13 & same & 17 & 17 & 13 & 0 \\
\hline $\begin{array}{c}\text { No of women in executive } \\
\text { committee }\end{array}$ & 4 & 5 & 3 & 25 & 4 & 9 & 5 & 125 \\
\hline No of women in major portfolio & 1 & 2 & 0 & 100 & 0 & 1 & 1 & 200 \\
\hline $\begin{array}{c}\text { No of Dalit in executive } \\
\text { committee }\end{array}$ & 0 & 1 & 1 & 100 & $\mathrm{~N} / \mathrm{A}$ & $\mathrm{N} / \mathrm{A}$ & NA & NA \\
\hline Selection of poor households & No & Yes & Con. & Yes & No & Yes & Yes & Yes \\
\hline $\begin{array}{c}\text { No of poor HHs in executive } \\
\text { members }\end{array}$ & $\mathrm{N} / \mathrm{A}$ & 1 & No & - & $\mathrm{N} / \mathrm{A}$ & $\mathrm{N} / \mathrm{A}$ & 1 & - \\
\hline
\end{tabular}

- Introduction, long-term and short-term objectives of OPs, historical background

- $\quad$ EIA, protection, conservation area, mitigation of negative environmental impacts

- $\quad$ Resources inventory of tree species and NTFPs, provision of inventory and annual allowable cut (AAC).

- Forest management (harvesting, silviculture, firewood, grazing and NTFP management)

- $\quad$ Biodiversity conservation method

- Forest product collection and distribution system

- Forest conservation method, punishment, rules and regulations

- Fund mobilization, provision of allowance, internal and external auditing

- Monitoring and evaluation
- $\quad$ Forest enterprises

- $\quad$ Miscellaneous (labour safety and training, provision of accepting FSC P \& C

Source: Kalobhir CFUG [10-13] and Lahare CFUG [17-20].

The OP of studied CFUGs was found tobe considerably improved in seven major areas in regard to certification requirements. The major shift in the OP were more detail inventory of major traded Medicinal and Aromatic Plants (MAPs) with management prescriptions, identification of major biodiversity threats and its reduction plans, provision of general environmental impacts assessment, and clear management objectives and activities (Table 2). Forest Stewardship Coucil (FSC) certification again developed criteria and indicators, including ecosystem services certification and Nepal is also in the final stage ofendorsement of national FSC standard. If we compare the FSC standardswith current management plan of sample CFUGs, we can find several gaps to get certified under FSC new standard. The current FSC standards are more stringent than previous FSC standards.

Table 2: Major changes in OP content after certification (2003, 2008 and 2016).

\begin{tabular}{|c|c|c|c|c|}
\hline \multirow{2}{*}{ Major Areas } & \multicolumn{2}{|c|}{ Kalobhir CFUG } & \multicolumn{2}{|c|}{ Lahare CFUG } \\
\hline & 2003 & $2008 / 2016$ & 2003 & $2008 / 2016$ \\
\hline $\begin{array}{c}\text { Introduction, long-term and short-term objectives of OPs, historical } \\
\text { background }\end{array}$ & NC (Not clear) & Yes/Yes & NC & Yes \\
\hline Clear objectives accordingly the management activities & No & Yes/Yes & No & Yes \\
\hline $\begin{array}{c}\text { EIA, Protection, conservation area, mitigation of negative } \\
\text { environmental impacts }\end{array}$ & No & Yes/Yes & No & Yes \\
\hline $\begin{array}{l}\text { Resources inventory of tree species and NTFPs', provision of } \\
\text { inventory and AAC. }\end{array}$ & Not detail (ND) & Yes/Yes & No & Yes \\
\hline $\begin{array}{l}\text { Forest management (harvesting, silviculture, firewood, grazing and } \\
\text { NTFP management) }\end{array}$ & ND & Detailed & ND & Detailed \\
\hline Forest product collection and distribution system & Open access & Equity based (EB) & Open access & $\mathrm{EB}$ \\
\hline Forest conservation method, punishment, rules and regulations & Not proper $(\mathrm{NP})$ & $\mathrm{EB} /($ same) & NP & $\mathrm{EB}$ \\
\hline $\begin{array}{l}\text { Fund mobilization, provision of allowance, internal and external } \\
\text { auditing }\end{array}$ & ND & Detailed & ND & Detailed \\
\hline Monitoring and evaluation & NC & Detailed & NC & Detailed \\
\hline Provision of forest enterprises & No & Yes & No & Yes \\
\hline $\begin{array}{l}\text { Miscellaneous (labor safety and training, provision of accepting FSC } \\
\qquad \text { P \& C }\end{array}$ & No & Yes & No & Yes \\
\hline Provision of poor focus program & $\mathrm{N} / \mathrm{A}$ & Yes & $\mathrm{N} / \mathrm{A}$ & Yes \\
\hline
\end{tabular}




\section{Implementation of constitution and operational plans}

Management objectives, provision of environmental impact assessment, forest inventory, forest management system, fund mobilization and punishments were assessed in ground level practices. In comparison with its previous OPs, fund mobilization and distribution systems were found balance for forest management, poor focused and institutional development better (Table 3). Out of 47 criteria of Forest Stewardship Council, 41 were applied in the field, however their level of implementation was varied $[3,9,21]$. Criteria developed for ecosystem services are more stringent and just recently made an assessment against them. So, it was not availablefor comparison.

Table 3: Implementation status as of 2003 to 2016.

\begin{tabular}{|c|c|c|c|c|}
\hline \multirow{2}{*}{ Major Areas } & \multicolumn{2}{|c|}{ Kalobhir CFUG } & \multicolumn{2}{|c|}{ Lahare CFUG } \\
\hline & 2003 & 2016 & 2003 & 2016 \\
\hline $\begin{array}{l}\text { EIA, protection, conservation area, mitigation of } \\
\text { negative environmental impacts }\end{array}$ & No & Well-Implemented (WI) & No & WI \\
\hline $\begin{array}{l}\text { Detail inventory of NTFPs and management } \\
\text { provision }\end{array}$ & No & WI & No & WI \\
\hline $\begin{array}{l}\text { Forest management (harvesting, silviculture, } \\
\text { firewood, grazing and NTFP management) }\end{array}$ & (ND) & As per plan (AP) & ND & AP \\
\hline Forest product collection and distribution system & Open access $(\mathrm{OA})$ & $(\mathrm{EB})$ & $\mathrm{OA}$ & $\mathrm{EB} / \mathrm{WI}$ \\
\hline $\begin{array}{l}\text { Forest conservation method, punishment, rules and } \\
\text { regulations }\end{array}$ & NP & EB & Not proper & $\mathrm{EB} / \mathrm{WI}$ \\
\hline $\begin{array}{l}\text { Fund mobilization, provision of allowance, internal } \\
\text { and external auditing }\end{array}$ & ND & WI & ND & WI \\
\hline Monitoring and evaluation & NC & WI & NC & WI \\
\hline Provision of forest enterprises & No & AP & No & Yes \\
\hline $\begin{array}{l}\text { Miscellaneous (labor safety and training, provision } \\
\text { of accepting FSC P \& C }\end{array}$ & No & AP & No & $\mathrm{AP}$ \\
\hline Provision of poor focus program & $\mathrm{N} / \mathrm{A}$ & AP & $\mathrm{N} / \mathrm{A}$ & AP \\
\hline
\end{tabular}

\section{Forest product management}

Before introducing FSC certification, one of the issues in the CFs was over-harvesting of selected plants. From the records and discussions with major stakeholders, we noticed that overharvesting was gradually minimized over a period of time. This is due to regular discussion with CFUG members in general assembly, conducting regular capacity building activities, following stock inventory and provisions of forest product collection in a schedule and guidance of collection and post harvesting methods. Community monitoring also helped much in stock management and regulation of products. Species like Lokta (Daphne bholua) which were vanishing from at local level was noticeably regenerated.

\section{Socio-economic impacts}

Shanley \& Medina [22] stated that NTFPs are the most critical resource to rural livelihoods. NTFPS provide communities with important subsistence resources like medicine, food and shelter, as well asthey are a source of cash income. NTFPs are a more difficult group of products to certify than timber due to a multitude of factors, including their exceedingly diverse and idiosyncratic nature, and social and ecological complexity. However, in spite of these challenges, latent opportunities exist to promote sound ecological and social practices in resource management and trade. During the study, it also found that FC initiated establishment of local level enterprises leading fair market price, generation of income and employment from forest management and establishment of local value-addition facilities.

The study team considered atotal of 11 important MAPs species in sample CFUGs. Among them, extensively traded are Lokta (Daphne spp), Argeli (Edgeworthiagardnerii), Chiraito (Swertiachirayita), Allo (Girardiniadiversifolia) etc. Similarly, timber depots were established to manage timber business and firewood depots were introduced for firewood management. Both were playing substantial role in supply of market and subsistence demands. The depots earlier non-existing value-chained the products and eased the market access, which are important in certification [23]. After establishment of the firewood depot in Kalobhir CFUG, the frequency of forest fire incidences was considerably reduced due to the removal of fuel load from forest, which enhanced sprouting and regeneration.

Despite the expectations of premium price from certification marketing, the induced market was largely environmentally friendly and limitedly multiplicated as evidenced by [24]. Molnar[25] suggested a $10 \%$ premium price to communities for their sustainable source of logs. Cashore et al. [23] estimated an account of premium price appear to be available to most producers in the Asia-Pacific by $37 \%$ and in Indonesia by $15 \%$ as a consequence of forest certification. Likewise, a positive account: marketing prospects was greatly improved in the village level and there is a positive trend for premium price of Argeli and Lokta sale in Kalobhir and Lahare CFUGs. In Kalobhir CFUG, after the establishment of community enterprise (Everest Gateway), users have received better price than before. Based on interview with collectors, local contractors, committee members and enterprise operators, price of some selected NTFPs were found to increase by $20-40 \%$ due to local level value addition facilities. CFUG members were expected premium price from FC but was not evident in selected CFUGs. 


\section{Market linkage}

The CFUGs has developed good linkages with national and international markets. Leading American Ayurvedic companies such as Aveda Corporation started to market after receiving forest certification standard from sample CFUGs. Himalayan Biotrade Pvt. Ltd, Kathmandu is only a certified market company which was able to develop linkages in US and Europe. In general, the export of hand-made paper was decreased by $13 \%$ but the overall trade of Himalayan Bio-trade (HBTL) was increased over a period of four years due to product certification. The total sale was worth of 0.6 million NRs in 2005, 8 million in 2008 and significantly high in 2016 i.e. NRs 30.45 million. This increment is due to forest certification as well as continued dealing with western markets and able to understand their market requirements. Certification sometimes improves organization of communities in order to conduct dialogue with government, industry and donors that is also applicable in the case of FECOFUN $[3,21]$. In most cases, communities were supported by donor projects or had a strong relationship with international NGOs because of better linkages [9].

To increase benefits to local communities, an attempt was made to change enterprise operation modalities. Network modalities were introduced to organize anenterprise operation and majority of CFUG members were involved. Public private partnership model was schemed and first introduced in Jiri during certification process and Kalobhir CFUG was one of the promoters of this initiative. The initiative was instrumental in generating employment at community level, network level and enterprise level (Table 4).

Table 4: Income and employment generated by CFUGs in 2008 and 2016 (parenthesis data is of 2016).

\begin{tabular}{|c|c|c|c|c|}
\hline \multirow{2}{*}{ Product Category } & \multicolumn{2}{|c|}{ Kalobhir CFUG 2008/ (2016) } & \multicolumn{2}{c|}{ Lahare CFUG 2008/ (2016) } \\
\cline { 2 - 5 } & HHs & Income (Rs) & HHs & Income (Rs) \\
\hline \multirow{2}{*}{ Lokta } & $10(20)$ & 105,000 & $(125)$ & N/A \\
& 150 & $193000)$ & & N/A \\
\hline \multirow{2}{*}{ Argeli } & $(90)$ & $(250000)$ & $50000 ;$ & $(50000)$ \\
\hline \multirow{2}{*}{ Allo } & - & - & 5 Q & 24,$000 ;$ \\
\hline \multirow{2}{*}{ Enterprises in operation } & 4 & 100,000 & 5 & N/A \\
\hline Timber & $9(22-25)$ & 100,000 & 8 & 150000 \\
\hline Firewood & N/A & 450000 & N/A & N/A \\
\hline
\end{tabular}

\section{Impacts to pro-poor households}

Up to $20-30 \%$ of the total fund of each CFUG (Lahare and Kalobhir) has been allocated for poor people for different program. This allocation is far better than the country average $3 \%[16]$ and the district average $8 \%$ [26] but it is yet to be improved as guided in community guidelines (35\%) (GoN, 2008). Poor households were involved in executive committee as well as they also became an owner of the enterprises. They were also prioritized on getting an opportunity in enterprise activities. In Lahare CFUG, a total of 15 households were identified as poor households, and they were getting several opportunities in forest management and enterprise activities. They were involved in Allo and Lokta collection, processing, and marketing activities. They were also involved in timber sawing and transportation. In Kalobhir CFUG, two identified poor families received job opportunities in forest-based enterprise. The poor households in this CFUG also received free and subsidized forest products including timber. It is claimed that the communities, indigenous peoples, local communities and workers perceived certification as a way to improve their social situation [27]. In the study area, indigenous and usufructs of yak herders have been secured and certain forest areas within the CFs (in Suspa and Charnawoti CFUGs, Dolakha as a case) have been allocated for cattle grazing [28-31].

\section{Improvement in governance situation in CFUG}

Improved administration system was adopted through better documentation of forestry operations, bookkeeping and reporting.
Record of forest products sales, financial expenses and opportunities were maintained in both CFUGs. Decision-making and participation were improved since certification emphasized transparent and equitable participation in community forest management. The information such as financial rules and regulations, forest products harvesting, and distribution system was found more transparent and made visible to most of the CFUG members [32-34]. Total income and expenditure were clearly presented and discussed during all executive meetings and kept informed through up-to-date information in brown sheet in CFUG office. This is a very simple, but it has created a positive attitude towards forest management and executive members too[35].

\section{CONCLUSION AND RECOMMENDATION}

This study revealed that the certification of forest has positive impacts both in socio-economic and governance perspectives. Forest certification seemed to be a vehicle for local value addition, income and employment generation. FChas decreased negative environmental consequences due to better facilitation an rural poverty reduction. Certification has a positive impact in sustainable resource management by creating awareness for improvement of collection of forest products, maintenance of records, and maintaining transparency of all process and methods. This has also improved the governance of community forest management and local enterprises. During FC process several enterprise models have been tested and established including public and private partnership, which is now replicated elsewhere across the country. 
It is imperative that the expanding certification will have a positive impact in improving natural resource governance and sustainable resource management and can be an avenue for trade of MAPs/ NTFPs in international markets.

\section{ACKNOWLEDGEMENT}

Authors are grateful to FECOFUN and the users of Lahare and Kalobhir CFUG. ANSAB isacknowledged for providing various information and venue for International Conference. We would also like to express our thanks to reviewers for their constructive comments.

\section{REFERENCES}

1. DoF (2016) Databse of department of forests. Ministry of forests and soil coservation, Babarmahal, Kathmandu, Nepal.

2. Ebeling J, Yasué M (2009) The effectiveness of market-based conservation in the tropics: Forest certification in Ecuador and Bolivia. Journal of Environmental Management 90(2): 1145-1153.

3. Acharya RP, Bhattarai B, Dahal NR, Kunwar RM, Karki G, et al. (2015) International forestry Review 17(1).

4. Upton C, Bass S(1995) The Forest Certification Handbook, Earth Scan publication, London, UK.

5. Fanzeres A, Vogt K (1999) Roots of forest certification: Its developmental history, Types of Approaches, and Statistics. In: Vogt K, Larson BC Gordon JC, et al. (Eds.), Forest certification, roots, issues, challenges and benefits. CRC Press LLC, USA.

6. Vajelo $N$ (2003) Certification of community forest management. In Meideneger E, Elliot C, Oesten G (Eds.), Social and Political dimensions of Forest Certification.

7. Subedi BP,Khanal SC, Ghimire PL (2015) Nepal: Himalayan Bio Trade Pvt Ltd Community-based handmade paper: a socially and environmentally responsible international business: In democratising forest business: a compendium of successful locally controlled forest business organisations. Duncan M. (Ed). Full Spectrum Print Media, UK.

8. Lewis RA, Davis SR (2015) Forest certification, institutional capacity and learning: An analysis of the impacts of the Malaysian timber certification scheme. Forest Policy and Economics 52(C): 18-26.

9. Acharya BP (2007) Practice and implementation of forest certification in Nepal: A case study from some CFUGs in Dolakha district. Masters in Mountain Forestry, BOKU University, Austria.

10. Kalobhir CFUG (2004a) Constitution of Kalobhir Community Forest User Group, Jiri, Dolakha, Nepal.

11. Kalobhir CFUG (2004b) Operational Plan of Kalobhir Community Forest User Group, Jiri, Dolakha, Nepal.

12. Kalobhir CFUG (2015d) Operational Plan of Kalobhir Community Forest User Group, Jiri, Dolakha, Nepal.

13. Kalohir CFUG (2015c) Constitution of Kalobhir Community Forest User Group, Jiri, Dolakha, Nepal.

14. Shanley P, Medina G (2006) Connecting through Culture: transforming forest research and extension for rural and urban relevance in the Brazilian Amazon. Proceedings of IUFRO.

15. FAO (2000) Certification and forest product labeling: A review. FAO Asia pacific forestry commission, eighteen sessions. Secretariat note Noosaville, Queensland, Australia.
16. Kanel KR, Poudyal RP, Baral JP (2006) Nepal Community Forestry 2005.

17. Lahare CFUG (2004a) Constitution of lahare community forest user group, Gadaraya, Nepal.

18. Lahare CFUG (2004b) Operational Plan of Lahare Community Forest User Group, Gadaraya, Nepal.

19. Lahare CFUG (2015d) Operational Plan of Lahare Community Forest User Group, Gadaraya, Nepal.

20. Lahare CFUG (2015c) Constitution of Lahare Community Forest User Group, Gadaraya, Nepal.

21. Acharya RP (2005) Concept of forest certification and its schemes. In: Forest certification in Nepal, application, achievement and opportunity. FECOFUN and ANSAB, Kathmandu, Nepal.

22. Shanley P, Luz L, Swingland I (2002) The Faint Promise of a Distant Market: a survey of Belem's trade in non-timber forest products. Biodiversity and Conservation, Kluwer Academic Publishers. The Netherlands 11: 615-636.

23. Cashore B, Gale F, Meidinger E, Newsom D (2006) Confronting sustainability: Forest certification in developing and transitioning countries. Yale F \& ES Publication series report no 8.

24. Nussbaum R, Simula M (2005) The forest certification handbook second edition, Earth Scan publication Ltd, London, UK.

25. Molnar A (2003) Forest certification and communities: Looking forward to the next decade. Forest trends, Washington DC, USA.

26. ANSAB (2005) Nepal NTFP alliance, final report submitted to USAID, Ravi Bhawan, Kathmandu, Nepal.

27. FSC (2003) Looking to the Future, 1993 (10 years of FSC).

28. ANSAB (2005a) Paper presentation on certification and sustainable marketing of NTFPs interaction workshop. Dolakha, Nepal.

29. ANSAB (2006) Advancing community forestry for sustainable enterprises in Nepal, review and planning workshop. Dolakha, Nepal.

30. Bouahong P, Katila M (1999) Village forestry in laos: Towards sustainable management. GoLPDR. Vientiane.

31. Dahal N (2006) Contribution of forest certification on bio-diversity conservation and fair-trade promotion in Nepal". Paper presented at $11^{\text {th }}$ Biennial Conference, Survival of the Commons: Mounting Challenges and New Realities. Organised by International Association for the study of common property (IASCP), 19-23 June 2006, Ubud, Bali, Indonesia

32. Go N (2008) Community forestry guidelines. Ministry of forest and soil conservation, Government of Nepal, Kathmandu, Nepal.

33. Kanel KR (2004) Twenty-Five years of community forestry: contributing to millennium development goals. In: Proceedings of the fourth national workshop on community forestry. Community Forest Division, Kathmandu, Nepal.

34. Pierce A, Shanley P, Laird S (2003) Certification of non-timber forest products: Limitations and implications of a market-based conservation tool. Paper presented at the International Conference on Rural Livelihoods, Forests and Biodiversity, Bonn, Germany.

35. Rametsteiner E (2000) Sustainable forest management certification. Frame conditions, system design and impact assessment. Ministerial Conference on the Protection of Forests in the Europe, European Commission. Vienna, Austria. 